\title{
HUBUNGAN ANTARA KESADARAN KARIR (CAREER AWARENESS) DAN DISIPLIN DIRI DENGAN PRESTASI BELAJAR PADA MAHASISWA BIDIKMISI PROGRAM STUDI PENDIDIKAN TEKNIK ELEKTRO UNIVERSITAS NEGERI JAKARTA
}

${ }^{1}$ Santi Selfiana, ${ }^{2}$ Soeprijanto, ${ }^{3}$ Irzan Zakir

${ }^{1,2,3}$ Pendidikan Teknik Elektro, Fakultas Teknik, Universitas Negeri Jakarta

1Email: santi.selfiana@gmail.com, soeprijanto@unj.ac.id,irzan.zakir@unj.ac.id

\begin{abstract}
The purpose of this study was to determine the relationship between career awareness and self-discipline with the learning achievement of bidikmisi students in the Electrical Engineering Education Study Program at the State University of Jakarta. Hypothesis in this study is suspected that there is a positive and significant relationship between career awareness and self-discipline with the learning achievement of bidikmisi students in the Electrical Engineering Education Study Program, State University of Jakarta.

This research is an ex-post facto research using a quantitative approach. The research subjects used were bidikmisi students of the Electrical Engineering Education study program at the State University of Jakarta with a sample of 29 students. Data collection techniques using questionnaires and documentation. The analysis technique used is the product moment correlation, hypothesis test and significance test.

The calculation result shows that the hypothesis test with $5 \%$ of significant level obtained $r_{\text {count }}=0.495>r_{\text {table }}=$ 0.367 then the value of $F_{\text {count }}=4.21>F_{\text {table }}=3.37$, if $r_{\text {count }}>r_{\text {table }}$ and $F_{\text {count }}>F_{\text {table }}$, it can be concluded that there is a positive and significant relationship between the relationship between career awareness and selfdiscipline with Student Learning Achievement in Bidikmisi Student Study Program in Electrical Engineering Education, State University of Jakarta.
\end{abstract}

Keywords : Career Awareness, Self-Discipline, Learning Achievement, Bidikmisi Students

\begin{abstract}
Abstrak
Tujuan penelitian ini adalah untuk mengetahui adanya hubungan antara kesadaran karir (career awareness) dan disiplin diri dengan prestasi belajar mahasiswa bidikmisi program studi Pendidikan Teknik Elektro Universitas Negeri Jakarta. Hipotesis dalam penelitian ini diduga bahwa terdapat hubungan yang positif dan signifikan antara kesadaran karir (career awareness) dan disiplin diri dengan prestasi belajar mahasiswa bidikmisi program studi Pendidikan Teknik Elektro Universitas Negeri Jakarta.

Penelitian ini merupakan penelitian ex-post facto menggunakan pendekatan kuantitatif. Subjek penelitian yang digunakan adalah mahasiswa bidikmisi program studi Pendidikan Teknik Elektro Universitas Negeri Jakarta dengan sampel sebanyak 29 mahasiswa. Teknik pengumpulan data menggunakan angket dan dokumentasi. Teknik analisis data yang digunakan adalah korelasi product moment, Uji Hipotesis dan uji signifikansi.

Hasil Penelitian menunjukkan bahwa uji hipotesis dengan taraf signifikan $5 \%$ diperoleh nilai $r_{\text {hitung }}=0,495>r_{\text {tabel }}=$ 0,367 , kemudian nilai $F_{\text {hitung }}=4,21 \geq F_{\text {tabel }}=3,37$. Jika $r_{\text {hitung }}>r_{\text {tabel }}$ dan $F_{\text {hitung }} \geq F_{\text {tabel }}$ maka dapat disimpulkan bah wa terdapat hubungan yang positif dan signifikan antara Hubungan antara Kesadaran karir (career awareness) dan Disiplin Diri dengan Prestasi Belajar Mahasiswa Bidikmisi Program studi Pendidikan Teknik Elektro Universitas negeri Jakarta.
\end{abstract}

Kata kunci : Kesadaran Karir, Disiplin Diri, Prestasi Belajar, Mahasiswa Bidikmisi

\section{PENDAHULUAN}

Pendidikan memegang peranan penting untuk membangun manusia yang berpengetahuan, bermoral, Oleh karena itu, perlu adanya peningkatan kualitas sumber daya manusia. Hal ini dapat dilakukan melalui berbagai macam cara, salah satunya melalui proses belajar.

Proses belajar dilakukan mulai dari jenjang SD,SMP,SMA sampai jenjang perguruan tinggi.
Namun, kondisi keluarga yang dianggap kurang mampu akan menjadi kendala seseorang untuk mengenyam pendidikan hingga ke jenjang perguruan tinggi. Hal tersebut sejalan dengan pendapat (Hartuti dan Frieda M, 2009 : 107) banyak penelitian membuktikan adanya korelasi antara kemiskinan dengan rendahnya prestasi belajar. Seseorang yang ingin melanjutkan kuliah namun memiliki keterbatasan biaya akan berusaha untuk memanfaatkan beasiswa yang 
ada. Salah satu beasiswa yang diperuntukkan untuk mahasiswa kurang mampu yaitu Bidikmisi.

Disisi lain banyak juga anak dari keluarga kurang mampu yang dapat berkembang dengan baik, memiliki prestasi, serta mampu bersaing dengan anak dari keluarga sejahtera. Pencapaian prestasi belajar menunjukan atau menggambarkan seberapa berhasil proses belajar yang telah terjadi. Berhasil atau tidaknya proses belajar dapat ditandai oleh prestasi yang dicapai oleh seseorang. Baik secara akademis (nilai ujian, penguasaan materi kuliah, keikutsertaan dalam lomba karya ilmiah dan lain-lain) yang dinyatakan dalam angka-angka maupun non akademis (keterampilan komunikasi, keterampilan organisasi, pengembangan kepribadian dan lain-lain).

Hasil prestasi belajar mahasiswa dapat dilih at dari indeks prestasi kumulatif (IPK). Namun, dari data beberapa mahasiswa program studi pendidikan teknik elektro indeks prestasi (IP) terjadi penurunan dan kenaikan setiap semester. Sehingga, prestasi belajar mahasiswa kurang optimal. Adapun faktor-faktor yang mempengaruhi prestasi belajar seseorang yaitu faktor internal dan faktor eksternal Faktor internal yang mempengaruhi prestasi belajar adalah aspek fisiologis (kesehatan dan kondisi tubuh individu) dan aspek psikologis (intelegensi, sikap, minat, motivasi, bakat). Sedangkan faktor eksternal meliputi faktor keluarga, lingkungan sekolah, lingkungan masyarakat, dan faktor waktu. Selain faktorfaktor tersebut, terdapat faktor lain yang juga mempengaruhi prestasi belajar yaitu kesadaran akan karir dan disiplin diri.

Tingginya tuntutan dunia usaha ditunjukkan melalui hasil survei yang menyebutkan bahwa 91\% kalangan dunia usaha beranggapan lulusan perguruan tinggi tidak siap pakai selepas kuliah (Kasih dan Suganda, dalam Rachmawati, 2012). hasil wawancara dalam penelitian (Yulia,dkk, 2017:4) hasil wawancara dari 15 mahasiswa dari 15 program studi berbeda fakultas keguruan dan ilmu pendidikan Universitas Lampung 5 orang mahasiswa (33\%) tidak tahu harus bekerja apa setelah lulus kuliah, sedangkan 3 orang mahasiswa $(20 \%)$ tidak ingin menjadi guru setelah lulus kuliah, selain itu terdapat 3 orang mahasiswa (20\%) tidak mengetahui minat dan bakat yang dimilikinya dan masih bingung memilih pekerjaan, dan 4 orang mahasiswa (26\%) yang ingin menjadi guru sesuai dengan pendidikan yang ditempuhnya saat ini.

Seseorang yang tidak memiliki gambaran rinci terkait pilihan karir yang mereka inginkan (misalnya instansi tempat bekerja, jobdesk dan gaji) kurang memahami potensi diri sendiri (minat dan bakat) Seseorang tersebut termasuk orang yang kurang memiliki kesadaran karir. Kurangnya kesadaran akan karir berdampak pada Ketidakmampuan dalam membuat keputusan karir yang akan mengakibatkan kerugian waktu, finansial, dan kegagalan belajar karena kurang motivasi untuk belajar.

Faktor yang mempengaruhi prestasi belajar selanjutnya adalah disiplin diri. Perilaku disiplin dan terarah dapat menghilangkan rasa malas. Disiplin adalah kunci sukses dan keberhasilan. Disiplin akan menjadikan hidup lebih teratur yang nantinya akan meningkatkan kemampuan belajar. Masalah yang sering muncul dalam ketidak disiplinan Mahasiswa berdasarkan hasil pengamatan peneliti di Program Studi Pendidikan Teknik Elektro seperti (1) ketidakhadiran dan (2) keterlambatan.

Berdasarkan hasil survey diatas, menjadi salah satu acuan penulis dalam melakukan penelitian untuk mengetahui apakah terdapat hubungan antara kesadaran karir dan disiplin diri dengan prestasi belajar pada mahasiswa bidikmisi. Sehingga penulis dapat memperkaya teori yang digunakan dalam mengkaji penelitian yang dilakukan dengan judul "Hubungan Antara Kesadaran Karir (Career Awareness) dan Disiplin Diri dengan Prestasi Belajar Pada Mahasiswa Bidikmisi Program Studi Pendidikan Teknik Elektro Fakultas Teknik Universitas Negeri Jakarta" .

\section{METODE PENELITIAN}

Metode penelitan yang digunakan adalah $E x$ post Facto yang bersifat deskriptif korelasional dengan pendekatan kuantitatif. Penelitian expost 
facto merupakan penelitian yang dilakukan untuk meneliti peristiwa yang telah terjadi dan kemudian merunut kebelakang untuk mengetahui faktor yang dapat menyebabkan kejadian tersebut terjadi tanpa diberi perlakuan oleh peneliti.

Penggunaan metode ini dimaksudkan untuk mengetahui hubungan kesadaran karir dan disiplin diri dengan prestasi belajar.

Dengan teknik pendekatan korelasi dapat pula dilihat hubungan antara variabel bebas (kesadaran karir) yang mempengaruhi dan diberi simbol $X_{1}$ dan (disiplin diri) yang mempengaruhi dan diberi simbol $X_{2}$ dengan variabel terikat (prestasi belajar) sebagai variabel yang dipengaruhi dan diberi simbol Y.

Pada Penelitian ini, yang termasuk kedalam populasi adalah Mahasiswa aktif angkatan 2018 , 2017, 2016, 2015 dan 2014 penerima beasiswa bidikmisi.

\section{Teknik Pengumpulan Data}

Penelitian ini terdapat dua variabel, yaitu Kesadaran Karir $\left(\mathrm{X}_{1}\right)$, Disisplin Diri $\left(\mathrm{X}_{2}\right)$ dan Prestasi Belajar (variabel $Y$ ). Data yang digunakan untuk mengukur variabel $\mathrm{X}_{1}$ dan $\mathrm{X}_{2}$ adalah dengan cara membagikan kuesioner berupa selembaran kepada responden. Sedangkan variabel Y dengan melihat data nilai IPK (indeks prestasi kumulatif) Mahasiswa.

\section{Teknik Analisis Data}

Teknik analisis data yang digunakan adalah secara deskriptif dan statistik inferensial. Analisis data deskriptif digunakan untuk menyajikan data melalui tabel, distribusi frekuensi, histogram, skor rata-rata dan simpangan baku. Sedangkan analisis inferensial digunakan untuk menguji hipotesis menggunakan analisis regresi dan korelasi.

\section{Uji Normalitas}

Uji normalitas data bertujuan untuk mengetahui apakah data yang akan dianalisis tersebut berdistribusi normal atau tidak. Jika data tersebut berdistribusi normal, maka proses analisis datanya menggunakan statistika parametrik (Pearson Product Moment Correlation).

Uji Linieritas

Menurut Sugiyono (2011 : 188) Uji linier merupakan pengujian yang dilakukan guna mengetahui apakah antara variabel bebas dan variabel terikat bersifat linier atau tidak. Uji linieritas dapat digunakan sebagai syarat dalam analisis korelasi atau regresi linier.

\section{Uji Hipotesis}

Untuk menguji hipotesis tersebut digunakan perhitungan korelasi. Perhitungan korelasi ini dilakukan untuk mengetahui hubungan antara kesadaran karir dan disiplin diri dengan prestasi belajar pada mahasiswa dan mengetahui besar kecilnya hubungan antara ketiga variabel yang diteliti menggunakan koefisien korelasi Product Moment (Sugiyono, 2015 :191).

Adapun rumusan hipotesis dalam penelitian ini adalah :

1. Terdapat hubungan yang positif dan signifikan antara kesadaran karir dengan prestasi belajar mahasiswa bidikmisi program studi pendidikan teknik elektro.

Penelitian ini menggunakan rumus korelasi Product Moment Untuk mengetahui apakah variabel $\mathrm{X}_{1}$ dan Variabel $\mathrm{Y}$ terdapat hubungan yang signifikan atau tidak. Maka dapat diuji mengunakan Uji Signifikansi Koefisien Korelasi menggunakan uji-T.

Untuk memprediksi seberapa tinggi nilai variabel terikat apabila nilai variabel bebas berubah-ubah, maka digunakan analisis regresi.

2. Terdapat hubungan yang positif dan signif ikan antara disiplin diri dengan prestasi belajar mahasiswa bidikmisi program studi pendidikan teknik elektro.

Penelitian ini menggunakan rumus korelasi Product Moment. Untuk mengetahui apakah variabel $\mathrm{X}_{2}$ dan Variabel $\mathrm{Y}$ terdapat hubungan yang signifikan atau tidak. Maka dapat diuji mengunakan Uji Signifikansi Koefisien Korelasi menggunakan uji-T.

Untuk memprediksi seberapa tinggi nilai variabel terikat apabila nilai variabel bebas berubah-ubah, maka digunakan analisis regresi. 
3. Terdapat hubungan yang positif dan signifikan antara kesadaran karir dengan disiplin diri pada mahasiswa bidikmisi program studi pendidikan teknik elektro.

Penelitian ini menggunakan rumus korelasi Product Moment. Untuk mengetahui apakah variabel $\mathrm{X}_{2}$ dan Variabel $\mathrm{Y}$ terdapat hubungan yang signifikan atau tidak. Maka dapat diuji mengunakan Uji Signifikansi Koefisien Korelas i menggunakan uji-T.

Untuk memprediksi seberapa tinggi nilai variabel terikat apabila nilai variabel bebas berubah-ubah, maka digunakan analisis regresi.

4. Terdapat hubungan yang positif dan signifikan antara kesadaran karir dan disiplin diri dengan prestasi belajar mahasiswa bidikmisi program studi pendidikan teknik elektro.

Penelitian Peneliti menggunakan rumus korelasi ganda. Sedangkan Untuk mengetahui apakah variabel $\mathrm{X}_{1}, \mathrm{X}_{2}$ dan Variabel $\mathrm{Y}$ terdapat hubungan yang signifikan atau tidak. Maka dapat diuji mengunakan uji signifikansi Koefisien Korelasi Berganda.

Untuk memprediksi seberapa tinggi nilai variabel terikat apabila nilai variabel bebas berubah-ubah, maka digunakan analisis regresi ganda.

\section{Hipotesis Statitiska}

\section{Variabel $X_{1}$ dan Variabel $Y$}

$\mathrm{H}_{0}: \mathrm{Ryx}_{1} \leq \mathrm{r}_{\text {tabel }}$, tidak terdapat hubungan antara kesadaran karir dengan prestasi belajar mahasiswa bidikmisi.

$\mathrm{H}_{\mathrm{a}}: \mathrm{Ryx}_{1}>\mathrm{r}_{\text {tabel}}$, terdapat hubungan antara kesadaran karir dengan prestasi belajar mahasiswa bidikmisi.

\section{Variabel $X_{2}$ dan Variabel $Y$}

$\mathrm{H}_{0}: \mathrm{Ryx}_{2} \leq \mathrm{r}_{\text {tabel }}$, tidak terdapat hubungan antara disiplin diri dengan prestasi belajar mahasiswa bidikmisi.

$\mathrm{H}_{\mathrm{a}}: \mathrm{Ryx}_{2}>\mathrm{r}_{\text {tabel}}$, terdapat hubungan antara disiplin diri dengan prestasi belajar mahasiswa bidikmisi.

\section{Variabel $X_{1}$ dan Variabel $X_{2}$}

$\mathrm{H}_{0}: \mathrm{Rx}_{1,2} \leq \mathrm{r}_{\text {tabel }}$, tidak terdapat hubungan antara kesadaran karir dengan disiplin diri.

$\mathrm{H}_{\mathrm{a}}: \mathrm{Rx}_{1,2}>\mathrm{r}_{\text {tabel}}$, terdapat hubungan antara kesadaran karir dengan disiplin diri.

\section{Variabel $X_{1}, X_{2}$ dan Variabel $Y$}

$\mathrm{H}_{0}: \mathrm{Ryx}_{1,2} \leq \mathrm{r}_{\text {tabel }}$, tidak terdapat hubungan antara kesadaran karir dan disiplin diri dengan prestasi belajar mahasiswa bidikmisi.

$\mathrm{H}_{\mathrm{a}}: \mathrm{Ryx}_{1,2}>\mathrm{r}_{\text {tabel }}$, terdapat hubungan antara kesadaran karir dan disiplin diri dengan prestasi belajar mahasiswa bidikmisi.

\section{HASIL \& PEMBAHASAN}

\section{Hubungan Antara Kesadaran Karir dengan Prestasi Belajar}

Berdasarkan hasil perhitungan product moment, diperoleh nilai $r_{\text {hitung }}$ sebesar 0,3958 dan $r_{\text {tabel }}$ sebesar 0,367 yang berarti $r_{\text {hitung }}>$ $r_{\text {tabel }}$. dengan demikian Ho ditolak karena $\boldsymbol{r}_{\text {hitung }}$ lebih besar dari $r_{\text {tabel }}$ sehingga regresi yang diperoleh adalah berarti. Sedangkan dalam uji signifikansi dibuktikan dari nilai $t_{\text {hitung }}$ sebesar 2,082 dan $t_{\text {tabel }}$ sebesar 2,051 yang berarti $t_{\text {hitung }}>t_{\text {tabel }}$. Maka $\mathrm{H}_{\mathrm{o}}$ diterima sehingga dapat disimpulkan terdapat hubungan yang signifikan antara kesadaran karir dengan prestasi belajar.

Analisis regresi linier sederhana terhadap pasangan data penelitian antara kemandirian belajar dengan kesiapan kerja menghasilkan koefisien regresi (b) sebesar 0,00392 dan konstanta (a) sebesar 2,71. Dari perhitungan, persamaan regresi yang digunakan untuk memprediksi kesiapan kerja berdasarkan kemandirian belajar adalah $\hat{\mathrm{Y}}=2,7165+$ $0,00392 X_{1}$

\section{Hubungan Antara Disiplin Diri dengan Prestasi Belajar.}

Berdasarkan hasil perhitungan product moment, diperoleh nilai $r_{\text {hitung }}$ sebesar 0,4618 dan $r_{\text {tabel }}$ sebesar 0,367 yang berarti $r_{\text {hitung }}>$ $r_{\text {tabel }}$. dengan demikian Ho ditolak karena $r_{\text {hitung }}$ lebih besar dari $r_{\text {tabel }}$ sehingga regresi yang diperoleh adalah berarti. Sedangkan dalam uji signifikansi dibuktikan dari nilai $t_{\text {hitung }}$ sebesar 
3,98 dan $t_{\text {tabel }}$ sebesar 2,051 yang berarti $t_{\text {hitung }}>t_{\text {tabel }}$. Maka $\mathrm{H}_{\mathrm{o}}$ diterima sehingga dapat disimpulkan terdapat hubungan yang signifikan antara disiplin diri dengan prestasi belajar.

Analisis regresi linier sederhana terhadap pasangan data penelitian antara kemandirian belajar dengan kesiapan kerja menghasilkan koefisien regresi (b) sebesar 0,0053 dan konstanta (a) sebesar 2,5707. Dari perhitungan, persamaan regresi yang digunakan untuk memprediksi kesiapan kerja berdasarkan kemandirian belajar adalah $\hat{Y}=2,5707+$ $0,0053 X_{2}$

\section{Hubungan Antara Kesadaran Karir dengan Disiplin Diri}

Berdasarkan hasil perhitungan product moment, diperoleh nilai $r_{\text {hitung }}$ sebesar 0,513 dan $r_{\text {tabel }}$ sebesar 0,367 yang berarti $r_{\text {hitung }}>r_{\text {tabel }}$. dengan demikian Ho ditolak karena $r_{\text {hitung }}$ lebih besar dari $r_{\text {tabel }}$ sehingga regresi yang diperoleh adalah berarti. Sedangkan dalam uji signif ik ansi dibuktikan dari nilai $t_{\text {hitung }}$ sebesar 6,85 dan $t_{\text {tabel }}$ sebesar 2,051 yang berarti $t_{\text {hitung }}>$ $t_{\text {tabel }}$. Maka $\mathrm{H}_{\mathrm{o}}$ diterima sehingga dapat disimpulkan terdapat hubungan yang signifikan antara kesadaran karir dengan disiplin diri.

Analisis regresi linier sederhana terhadap pasangan data penelitian antara kemandirian belajar dengan kesiapan kerja menghasilkan koefisien regresi (b) sebesar 0,4365 dan konstanta (a) sebesar 64,558. Dari perhitungan, persamaan regresi yang digunakan untuk memprediksi kesiapan kerja berdasarkan kemandirian belajar adalah $\hat{Y}=64,5585+$ $0,4365 X_{1,2}$.

\section{Hubungan Antara Kesadaran Karir dan Disiplin Diri dengan Prestasi Belajar}

Berdasarkan hasil perhitungan product moment, diperoleh nilai $r_{\text {hitung }}$ sebesar 0,495 dan $r_{\text {tabel }}$ sebesar 0,367 yang berarti $r_{\text {hitung }}>r_{\text {tabel }}$. dengan demikian Ho ditolak karena $r_{\text {hitung }}$ lebih besar dari $r_{\text {tabel }}$ sehingga regresi yang diperoleh adalah berarti. Sedangkan dalam uji signif ikansi dibuktikan dari nilai $\mathrm{F}_{\text {hitung }}=4,21$ dan $\mathrm{F}_{\text {tabel }}=$ 3,37 yang berarti $t_{\text {hitung }}>t_{\text {tabel }}$. Maka $\mathrm{H}_{\mathrm{o}}$ diterima sehingga dapat disimpulkan terdapat hubungan yang signifikan antara kesadaran karir dan disiplin diri dengan prestasi belajar.

Koefisien determinasi $\mathrm{KD}=\mathrm{r}_{\mathrm{x} 1 \mathrm{x} 2 \mathrm{y}}{ }^{2} \mathrm{x} 100 \%$ $=(0,495)^{2} \times 100 \%=24,4 \%$ Hasil pengujian menunjukkan bahwa koefisien determinasi $\left(\mathrm{r}^{2}\right)$ sebesar 24,4 \% dapat disimpulkan bahwa kontribusi prestasi belajar ditentukan oleh kesadaran karir dan disiplin diri sebesar 24,4\% dan sisanya 75,6\% ditentukan oleh variabel lain.

Analisis regresi linier berganda terhadap pasangan data penelitian antara kemandirian belajar dan sikap ilmiah dengan hasil belajar menghasilkan koefisien regresi (c) sebesar 0,004089 dan (b) sebesar 0,002157 serta konstanta (a) sebesar 2,68 Dari perhitungan, persamaan regresi yang digunakan untuk memprediksi hasil belajar berdasarkan kemandirian belajar dan sikap ilmiah adalah $\hat{Y}=$ $2,68+0,002157 X_{1}+0,004089 X_{2}$.

\section{KESIMPULAN DAN SARAN}

\section{a. Kesimpulan}

Berdasarkan pembahasan yang telah diuraikan sebelumnya, maka diperoleh kesimpulan sebagai berikut:

Dari penelitian dan pengolahan data yang sudah dilakukan oleh peneliti menyatakan bahwa, terdapat hubungan yang positif dan signifikan antara kesadaran karir dan disiplin diri dengan prestasi belajar mahasiswa bidikmsi. Hal ini ditunjukkan dengan uji korelasi yang

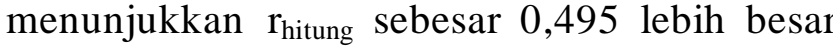
daripada nilai $r_{\text {tabel }}=0,367$. Koefisien determinasinya $\left(\mathrm{r}^{2}\right)=24 \%$. Hal ini berarti variabel kesadaran karir dan disiplin diri dengan prestasi belajar sebesar $24 \%$ dan $76 \%$ dipengaruhi oleh faktor lain.

\section{b. Saran}

Berdasarkan hasil penelitian ini, penulis mempunyai saran antara lain :

1. Mahasiswa harus menyadari pentingnya memiliki kesadaran karir untuk meningkatkan prestasi belajar. Karena dengan memiliki kesadaran karir dan mendapatkan prestasi 
belajar yang baik akan menjadi bekal untuk mempersiapkan diri men ghadapi dunia kerja.

2. Mahasiswa harus memiliki sikap disiplin diri dan dapat menerapkannya dikehidupan seharihari. Disiplin diri yang tinggi akan menjadi kebiasaan yang baik dan memberikan dampak yang positif untuk pendidikan dalam hal prestasi belajar maupun di dunia kerja.

\section{DAFTAR PUSTAKA}

[1] Hartuti dan Mangunsong,Frieda M. 2009. Pengaruh Faktor-faktor Protektif Internal dan Eksternal pada Relisiensi Akademis Siswa Penerima Bantuan Khusus Murid Miskin (BKMM) di SMA Negeri Depok. Jurnal Psikologi Indonesia. 6 (2). Hal. 107 118.

[2] Rachmawati, Yunia Eka. 2012. Hubungan Antara Self Efficacy dengan kematangan karir pada Mahasiswa Tingkat Awal dan Tingkat Akhir di Universitas Surabaya. Jurnal Ilmiah Mahasiswa Universitas Surabaya. 1 (1). Hal. 1-25

[3] Yulia, Anggi, Syarifuddin Dahlan dan Ratna Widiastuti. 2017. Penggunaan IEKAD (Inventori Eksplorasi Karir Arahan Diri) untuk Membantu Meningkatkan Pemahaman Diri Vocational Mahasiswa. Jurnal Ilmiah FKIP Universitas Lampung. 5 (4). Hal. 94-108.

[4] Sugiyono. (2011). Statistika Untuk Penelitian. Bandung: Alfabeta.

[5] Sugiyono. (2015). Metode Penelitian Pendidikan Pendekatan Kuantitatif, Kualitatif, dan R\&D. Bandung: Alfabeta. 